Reflection - 891 -

http://dx.doi.org/10.1590/0104-07072015002660014

\title{
CAUSES OF INFANTILE-JUVENILE OBESITY: REFLEXIONS BASED ON THE THEORY OF HANNAH ARENDT
}

\author{
Larissa Soares Mariz', Bertha Cruz Enders², Viviane Euzébia Pereira Santos³, Francis Solange Vieira \\ Tourinho ${ }^{4}$, Caroline Evelin Nascimento Kluczynik Vieira ${ }^{5}$
}

\footnotetext{
${ }^{1}$ Doctoral student of the Programa de Pó-Graduação de Enfermagem (PGENF), Universiadade Federal do Rio Grande do Norte (UFRN). Natal, Rio Grande do Norte, Brazil. E-mail: larissamariz@gmail.com

${ }^{2}$ Ph.D. in Nursing. Professor, PGENF/UFRN. Natal, Rio Grande do Norte, Brazil. E-mail: bertha@ufrnet.br

${ }^{3}$ Ph.D. in Nursing. Professor, PGENF/UFRN. Natal, Rio Grande do Norte, Brazil E-mail: vivianeepsantos@gmail.com

${ }^{4} \mathrm{Ph} . \mathrm{D}$. in Child and Adolescent Care. Professor in the Nursing Department, Universidade Federal de Federal Santa Catarina. Professor, PGENF/UFRN. Florianópolis, Santa Catarina, Brazil. E-mail: francis.tourinho@ufsc.br

${ }^{5}$ Doctoral student, PGENF/UFRN. Natal, Rio Grande do Norte, Brazil E-mail: carolinekluczynik@gmail.com
}

\begin{abstract}
The objective of this study was to reflect on the causes of obesity beyond physical, genetic and biological factors. It is based on the understanding of the human condition and its associated economic and social relationships, derived from Hannah Arendt's Theory of The Human Condition and relevant literature. The satiety-need cycle and the technological advances of modern society cause consumerism, a sedentary lifestyle that affects children's health and nutritional education, and an increase of body fat in people. The causes of obesity surpass the direct results of excessive caloric intake and indicate the need to consider the person's social and economic context. Health professionals need to understand the existing relationship of the self with the socioeconomic, cultural, and political factors that determine obesity in children and adolescents.
\end{abstract}

DESCRIPTORS: Obesity. Children. Adolescents.

\section{CAUSAS DE OBESIDADE INFANTOJUVENIL: REFLEXÕES SEGUNDO A TEORIA DE HANNAH ARENDT}

RESUMO: O objetivo do estudo foi refletir sobre as causas da obesidade para além do físico, genético e biológico, partindo do entendimento da condição humana e das relações econômicas e sociais associadas. Tomou-se por base os pressupostos da Condição Humana de Hannah Arendt e literatura pertinente. O ciclo gerado pela saciedade e falta, somado ao avanço tecnológico imposto pela sociedade moderna, traz consigo um estilo de vida consumista e sedentário, afetando o estado de saúde dos filhos, a educação nutricional e o acúmulo de gordura corporal nas pessoas. Percebe-se que as causas da obesidade ultrapassam o resultado direto da ingestão calórica maior do que o gasto energético, tornando-se necessário considerar o meio social e econômico em que o indivíduo está inserido. Os profissionais de saúde necessitam compreender a relação do ser com os fatores socioeconômicos, culturais e políticos que condicionam a presença de obesidade em crianças e adolescentes.

DESCRITORES: Obesidade. Crianças. Adolescentes.

\section{CAUSAS DE LA OBESIDAD INFANTIL: REFLEXIONES SEGUNDO LA TEORÍA DE HANNAH ARENDT}

\begin{abstract}
RESUMEN: El objetivo de este estudio fue reflejar sobre las causas de la obesidad más allá de la condición física, genética y biológica, de acuerdo con los aportes de la condición humana y las relaciones económicas y sociales de la Condición Humana de Hannah Arendt y la literatura pertinente. El circulo de saciedad y necesidad, y los efectos de los avances tecnológicos en la sociedad moderna traen el consumismo, estilo de vida sedentaria que afecta la salud y la educación nutricional de los niños, y el aumento de la gordura corporal. Las causas de la obesidad exceden los resultados de la ingestión de calorías más de lo necesario, lo que indica la necesidad de considerar el ambiente socioeconómico de la persona. Profesionales de la salud necesitan comprender la relación entre los factores socioeconómicos, culturales e políticos que determinan la obesidad en niños y adolescentes.
\end{abstract}

DESCRIPTORES: Obesidad. Niños. Adolescentes. 


\section{INTRODUCTION}

Overweight/obesity is the nutritional problem of major concern at the beginning of the $21^{\text {st }}$ century, both because of its rapid and progressively increasing prevalence and because these phenomena occur at all stages of life, from childhood to late adulthood, as noticed in the high prevalence of elderly people with excess weight. ${ }^{1}$ The situation of children and adolescents is especially highlighted because disease in this age group persists throughout life. ${ }^{2}$

National data from 2008 and 2009 showed that one in three children, aged five to nine years, was overweight or obese. Among adolescents, $21.7 \%$ of males and $19.4 \%$ of females had this problem. These results reaffirmed that overweight is the main nutritional problem within this age range. ${ }^{3}$

Children and adolescents are subject to the socioeconomic and cultural conditions of their families, which influence their physical activity and the amount and type of food they have available. In addition, the current generation of children and adolescents has free access to technology such as computers, video games, cell phones and tablets without a limit on time spent in front of screens. This access favors investing a longer time in activities that require less energy expenditure. ${ }^{4}$ This is the origin of the factors that predispose the whole family to overweight, due to the contribution of an obesity-prone environment. ${ }^{5}$

Obesity can be conceptualized as a condition with multiple causes resulting from an imbalance between caloric intake and energy expenditure, and it can be determined by genetic, pathophysiological, environmental, behavioral, social and cultural factors. ${ }^{6}$

Some of the factors influencing the development of non-communicable diseases, such as obesity, are the individual's social and economic contexts, because the physical environment and social standards make it difficult to buy healthy food and live a healthy lifestyle, thereby producing inadequate behaviors such as poor diet, physical inactivity, and excessive weight. ${ }^{7}$

Thinking philosophically about overweight-related factors in children and adolescents, including the socioeconomic factors, assists in reflecting on the reality of the increasing numbers of obese and overweight people in all economic classes, in order to capture its deeper meanings.

This reflection is relevant given that, although epidemiological studies have their share of contribution in constructing knowledge and often guiding public health actions, the mechanism that relies on linear cause-effect relationships based on a numerical representation that is void of meaning does not allow for a deep understanding of the various facets of a complex object. Therefore, a philosophical understanding of the complex phenomenon of overweight/ obesity and the related socioeconomic factors is essential in order to collaborate on the development of control actions.

In addition, when it comes to obesity, especially in children and adolescents, there is a gap in the construction of philosophical knowledge that leads to an understanding of the causal aspects, as well its consequences and control actions.

In this context, this study intends to contribute to the understanding of obesity in its relationship with the socioeconomic status as a causal factor of the disease, derived from Hannah Arendt's philosophical perspective about human existence and consumerism.

Hannah Arendt (1906-1975), a German political philosopher of Jewish origin, addresses the human condition and its temporality. The author's reflection on the political practice of the human being is evidenced in the triad of activity: labor, work and action. The first element of the triad is performed as a supply of human biological requirements (homo laborans); the second element is performed as a means of transforming nature into durable objects shared by humans (homo faber) and, finally, action is the way of men relating with their political ability. ${ }^{8}$

Seeking to defend from the action and to dominate oneself, man seeks to replace action by manufacturing goods, a perspective that leads to capital and wealth accumulation. This dynamic of human existence generates a cyclical action between consumerism and need, and permeates the metabolic needs of man, entering Modernity, the era of excessive work (labor and faber) in the pursuit of satiety. ${ }^{8}$

These conceptual references were used as tools for a wider understanding of the causes of 
obesity in childhood and youth. Thus, this study aimed to reflect on the causes of obesity beyond the physical, genetic and biological factors, based on an understanding of the human condition and the economic and social relationships associated with it.

Therefore this is a reflective study about the theoretical and philosophical conception of the human condition, and its economic and social relationships, as developed by Hannah Arendt, and on the socioeconomic causal aspects of obesity in childhood and youth. Hannah Arendt's assumptions on the human condition, and relevant literature, were used for this reflection.

The concept of the research method used depicts a possibility of flexibility in generally static common definitions, in order to transpose the formal barriers of modern disciplines, articulating the theory, its background and use.

\section{HANNAH ARENDT'S THEORETICAL AND PHILOSOPHICAL CONCEPTS OF CONSUMPTION}

Beginning with ancient beliefs about man's creation or emergence, man found himself condemned to survive and obtain food using his own effort. The Western culture, in turn, introduced a model of man and life for subsistence. Hanna Arendt names this process the human condition.

Unlike the concept of human nature, the human condition refers to the requirements that tend to meet man's existence, which differs depending on the place and historical moment to which he belongs. In this sense, all beings, even those who condition the behavior of others, are conditioned to become conditioned by the very movement of conditioning. ${ }^{9}$

When an individual is born, even though he does not desire or understand, he brings newness, a new order, a single individual to a human community, and establishes a new channel with what was in the world. Hanna Arendt conceives this as the human condition from birth. Man relates to what is in place and begins to adapt to the lifestyle of those around him. This aspect is called equality. However, the individual is more complex than that; he has another aspect to be considered, which is distinction, i.e., each man has his peculiarities, and discussing the differences is needed for coexistence. Therefore, understanding equality and the distinction between men is the basis for understanding the man in his plurality. ${ }^{9}$

Since Aristotle, men's activities are divided into two groups: those relating to the 'life of the spirit' or the contemplative life (thinking, willing and judging) and, worldly activities, relating to the 'active life' (labor, work and action). Each of these activities aims to meet the objectives that originate from the human condition.

According to Arendt, there are three fundamentally human activities originating from birth: labor, work and action. Work strives to meet the requirements of the human condition of biological activity; labor is the activity aimed at meeting the human condition of building a habitat on the natural world, i.e., an artificial, lasting world of components; and, action takes place between men, without mediation of things or materials. ${ }^{8}$

It should also be noted that the activity of action takes place between men without a mediation of things or materials. Action aims to meet the human condition of plurality, in which men are able to live together, and to meet one's own condition, which is singularity, the fact that each man is a unique individual. Action seeks to enable man to live together, among his fellows, and relates to the human 'business': communication being mediated by the plurality of political opinions. ${ }^{8}$

This philosopher fragments the active life into two spheres: the public and private domains. Labor and production (work) are in the private domain sphere, whereas action is exclusively in the public domain sphere (politics). The private domain is the realm of necessity. The public domain is the realm of freedom. ${ }^{8}$

"Not only men of action, but also men of thought have always searched for a substitute for action" $8: 275$ The change seeks protection against the action accidents, in which man is master of his acts. In this context, action is replaced by manufacturing, which seeks to achieve a supposedly superior means that, in modernity, is represented by productivity in pursuit of the progress of society.

The replacement of action by the manufacturing process leads to consumerism and accumulation of wealth, which are framed in labor. 
When wealth is no longer a means of ensuring the preservation of human life and the satisfaction of (individual and species) basic needs, it becomes an end in itself. From there, occurs the birth of what we call capital, a process that exclusively and increasingly seeks the production of wealth: an endless cyclical process. ${ }^{8}$

Homo faber, the world manufacturer, replaces his ideals for the satisfaction of plenty. This satisfaction, articulated with the environment, generates an inexhaustible production of wealth, called the 'production-consumption scheme', which only guarantees the growth of wealth to the very producer or holder of the capital and the means of production. ${ }^{8}$ In this scheme, consumption, not wealth, is the intention of the consumer, to purchase and have more every day.

It is important at this point to understand the concept of mass society, which is a context in which the individual's life desires and interests are produced on a large scale for the manufacturing and consumption imposed by modern society, in which the individual is apathetic regarding public questions. ${ }^{10}$ For the philosopher, this phenomenon has given rise to a kind of degenerate being, reaching the summit of "perverse mutation," $8: 153$, when he will only obey the stimuli.

Massification and control can be cited as characteristics of this mass society. Massification refers to the configuration of the same way of existence to be followed by everyone, which spreads the heinousness of differences and encourages the behavior as obedience. Control refers to controlling consumption, of ways of being, of the general processes of existence. ${ }^{10}$ In the early $21^{\text {st }}$ century, control can be performed by opinion maker resources, such as the media, bureaucracy and the school, which are basic and indispensable tools for modeling of the social structure and modes of being and becoming.

Framed in the mass process and appearing controlled by the ideological apparatuses, consumption is expressed as a behavioral tendency in society. It is a way of being ordinary in search of satisfaction, living the myth of satiety and happiness.

By analyzing this in isolation, it can be stated that satiety is fleeting, because this is the implication of a process in place which is part of 'consume something'. This desire is equivalent to meeting desires, appetites, needs, goals. The body is the main target of this process, aimed at satisfying one's thirst, hunger, sexual desire, cold, heat, recognition, company, among others. This is an endless process, whose main feature is the specifics of biological life. For Arendt, the human activity that aims to meet the vital needs is labor. Labor provides satiety to biological life, prioritarily. ${ }^{8}$

The assignment of a vicious circle alternating satiety and need is part of the biological satiety movement. The social scheme of production and consumption takes advantage of it, causing more production to be necessary to provoke more consumption. The need-satiety-need relationship is spread across all areas of life, not only the biological area. ${ }^{10}$

As an example, the Greeks sought the opposition of the need-satiety-need process in their sagas. While the Greeks sought to gain immortality, fame and glory, the act of today's society is committed to satisfying vital needs, whether natural or unnatural. Thus, one gives in to the maintenance of satiety and supply of full beliefs and increasingly wishes to be satisfied, even if, in some way, one will be swallowed by the need. One engages more deeply every day into the vicious cycle of need, production, consumption, satiety, need. ${ }^{9}$

From this perspective, individuals with obesity are seeking greater nutrition than body requirements; they give in to the urge to satiate, and by doing so, feel the need of feeling not satiated. This condition is called binge eating, frequent in people with obesity. This compulsion occurs when a person eats a much larger amount of food in less time than he/she would normally eat, feeling a loss of control. ${ }^{11}$

\section{CONTRIBUTION OF HANNAH ARENDT'S THEORY TO THE UNDERSTANDING OF SOCIOECONOMIC ASPECTS RELATED TO INFANTILE-JUVENILE OBESITY}

The socioeconomic aspects of obesity have become prominent in research conducted in recent years, pointing to the growth of obesity in lower, medium and high-class families. This causal factor is even more clearly evidenced in children and adolescents, since they depend on their parents for feeding. The family is responsible for the feeding 
performance of this age group, since parents are the first nutritional educators.

The concepts of human condition and active life, as approached by Hannah Arendt, can be applied to the context of infantile-juvenile obesity. From birth, a being comes with the new, singular, relating to the environment - human condition. When the new arrives in a family with an obesogenic environment, the child and the teenager, by suffering family conditioning, will be integrated into this context and tend to have the same practices. Beyond the plurality of each individual, family conditioning directly influences food choices and children's and adolescents' lifestyle habits, generating the gradual development of overweight.

Man is a conditioned being, since everything that he comes in contact with becomes a condition of his existence. Thereby, conditioning, appointed by the philosopher, plays its active role in the family, when poor eating and lifestyle habits (considering lifestyle as physical activity, hours in front of television, video games, and others) step into this reality and endure to become the being's new human condition.

Technological and scientific developments also condition human beings. As an example, we can mention the introduction of informatics and technology, when humanity suffers a kind of mutation and starts to depend on this new technology that evolves daily. Thus, dependent on this new way of living, the culture of minimal efforts has been disseminated in society, and brings with it a new lifestyle: the sedentary one. All commands are sent by remote controls; electronic gadgets, such as the microwave are programmed to produce and respond quickly and instantly; the leisure activities of children and adolescents are reduced to video games and television; energy expenditure is reduced to a minimum, favoring weight gain. Therefore, children and adolescents have changed the physical activity levels from moderate or intense to low energy expenditure in their leisure activities. $^{12}$

In parallel, there is a lack of family involvement in the nutritional education of its children. Labor and work, a condition imposed by man for his own kind and the result of a cultural process, require mastery over the actual biological needs and preservation of life, and begin to take productivity, as a main order of modernity. At this point is the relentless pursuit of wealth production, which displaces parents from their role as drivers of appropriate nutritional practices of their children and places them in conditions with excessive working hours.

The increase in parents' working hours and the expansion of production and consumption of frozen (industrial) food are important factors in the transition of children's eating habits. ${ }^{12}$ In the educational context, commercializing of schools and their products, as well as exposing children to images of commercial advertisements, strengthen the consumer society because citizenship education is warped to produce acritical consumers. ${ }^{13}$

Consumption imposed by modern society, and produced by the social scheme of productionconsumption, has fast and low cost food, leading individuals in an immediacy society to reduce the time spent on preparation of nutritious foods and increasing the consumption of canned, processed and fast food. To paraphrase Arendt, "the spare time of the animal laborans is never spent in anything but consumption, and the more time left to him, the greedier and more craving his appetites $^{\prime \prime} 8: 5$

In this context, the media promotes the idea of massification, in which all need to adjust to consumption patterns and obey them. Those who do not fit into this process are marginalized by society. The influence of advertising and the advertising market are also present in the lives of children, considered consumers by industry companies. Many of the television commercials during the TV shows watched by children are about foods with low nutritional value. Therefore, the food industry exerts its control over food consumption. As an example, fast-food companies induce the younger population (children and adolescents) to consume their products and to be exalted as privileged to be part of this group, reducing prices and offering "freebies" for children's snacks.

Food manufacturers make various highenergy and satiety-promoting foods available. These are acceptable and affordable foods, making them accessible to both high and low-income classes. ${ }^{12}$ For the age group addressed here, it is essential to be a member of the consuming public of these companies, not caring about the harmful consequences to health. 
School canteens are also inserted in this context of companies that exercise control over society. Children and adolescents in pre-school and of school age tend not to want homemade snacks at school, because they are influenced by consumerism, present in society and, consequently, schools. They begin to spend time in the only company offering food in educational institutions: canteens. The canteens, in turn, provide fried foods, soft drinks, sweets, pasta, and other foods that lead to the accumulation of body fat, ${ }^{14}$ without worrying about the availability of healthy snacks. Consumers are controlled by supply.

The human beings walk in search of satiety as a happiness myth. But what it is really necessary to life? Meeting the biological needs such as hunger, or extrapolating it in order to experience the most sophisticated appetites of consumerism, focusing on the superfluities of life?

\section{FINAL REMARKS}

Given this reflection, it was possible to realize that the causes associated with obesity go beyond the physical, genetic and biological issues. We understood that there is a relationship of being with socioeconomic factors, as Arendt exposes in the philosophical thought of the human condition, which can condition the presence of obesity in children and adolescents. That is because the family environment is a determining factor in the amount and type of food consumed, healthy or unhealthy, purchasing power and regular physical activity. These factors, together, increase the risk for obesity.

It is necessary that health care professionals break with the Cartesian thought that obesity is a direct result of an energy intake that is higher than expenditure, without considering the social and economic environment in which individuals belongs, as well as their human condition and political practices.

The daily life, cultural and social factors despise the action of socioeconomic factors and reinforce the absorption of consumerism (labor) and the removal of oneself and others, encouraging the development of obesity.

Labor disruption by action can free individuals from consumption and the vicious circle of satiety. This fact would make new opinions arise, exceed obedience seeking to innovate through the act of expressing our humanity, breaking with social behaviors that lead parents to the same causal errors of infantile-juvenile obesity.

\section{REFERENCES}

1. Kumpel DA, Sodré AC, Pomatti DM, Scortegagna HM, Filippi J, Portella MR, et al. Obesidade em idosos acompanhados pela estratégia de saúde da família. Texto Contexto Enferm. 2011 Set; 20(3):471-7.

2. Mareno N. Parental perception of child weight: a concept analysis. J Adv Nurs. 2014 Jan; 70(1):34-45.

3. Ministério do Planejamento (BR). Pesquisa de Orçamentos Familiares (POF) 2008-2009: despesas, rendimentos e condições de vida. Brasília (DF): IBGE; 2010.

4. Pearson N, Biddle SJH. Sedentary behavior and dietary intake in children, adolescents and adults: a systematic review. Am J Prev Med [online]. 2011 [acesso 2015 Mar 18]; 41(2):178-88. Disponível em: http:/ / ac.els-cdn.com/S0749379711002996/1-s2.0S0749379711002996-main.pdf?_tid=f4495d38-cdaf11e4-aaa8-00000aab0f26\&acdnat $=1426711813$ _ db8f54fc74a5fcdbb1cf30d2e114e592

5. Camargo APPM, Barros FAA, Antonio MARGM, Giglio JS. A não percepção da obesidade pode ser um obstáculo no papel das mães de cuidar de seus filhos. Ciênc Saúde Coletiva. 2013; 18(2):323-33.

6. Hernandes F, Valentini MP. Obesidade: causas e consequências em crianças e adolescentes. Rev Facul Educ Física UNICAMP. 2010; 8(3):47-63.

7. Bezerra VM, Andrade ACS, César CC, Caiaffa WT. Comunidades quilombolas de Vitória da Conquista, Bahia, Brasil: hipertensão arterial e fatores associados. Cad Saúde Pública. 2013; 29(9):1889-902.

8. Arendt H. A condição humana. $11^{\mathrm{a}}$ ed. Rio de Janeiro (RJ): Forense Universitária; 2013.

9. Critelli D. Consumo e obediência: a desarticulação da liberdade. Psicol USP. 2008; 19(4):477-85.

10. Duarte AM. Hannah Arendt e a modernidade: esquecimento e redescoberta da política. Trans/ Form/ Ação. 2001; 24(1): 249-72.

11. Treasure J, Claudino AM, Zucker N. Lancet. 2010 Feb 13; 375(9714):583-93.

12. Sichieri R, Souza RA. Estratégias para prevenção da obesidade em crianças e adolescentes. Cad Saúde Pública. 2008; 24(Sup 2):209-34.

13. Norris T. Hannah Arendt \& Jean Baudirillard: pedagogy in the consumer society. Studn Philos Educ [online]. 2006 [acesso 2015 Mar 18]; 25(6):45777. Disponível em: http://link.springer.com/ article/10.1007/s11217-006-0014-z 
14. Guedes DP, Neto JTM, Almeida MJ, Silva ATRM. Impacto de fatores sociodemográficos e comportamentais na prevalência de sobrepeso e obesidade de escolares. Rev Bras Cineantropom Desempenho Hum. 2010, 12(4):221-31. 